\title{
Experimental study of RC beams strengthened for bending by reinforced grout layer and connectors
}

\section{Estudo experimental em vigas de CA reforçadas à flexão por encamisamento e conectores}
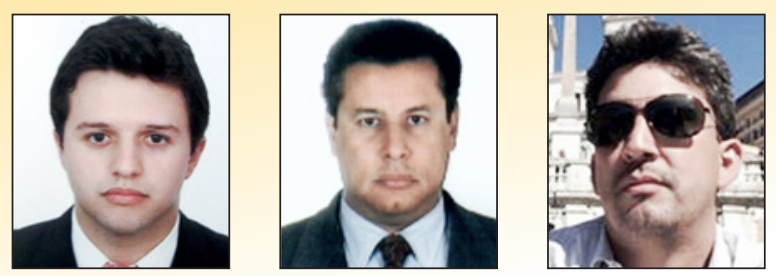

J. H. CANAVAL a
junior.canaval@ifmg.edu.br

T. J. DA SILVA ${ }^{b}$ tjdsilva@gmail.com

A. C. SANTOS acds.pir@gmail.com

\begin{abstract}
This work is based on an experimental investigation of reinforced concrete beams strengthened to flexure for wrapping applying a type of metallic connector in the bond substrate/groute. The experimental program consisted of 5 beams used for reference (without strengthening), 5 beams reinforced with surface brushed texture substrate and 5 beams with metal connectors bonded to the substrate. The beams were submitted to four-point load bending test. Initially with a partial loading, executed the strengthening and were finally tested until the break. The strengthening was made up by the increase by graute, on the sides and bottom of the beam and reinforcing. The applied force, the displacement, deformations in steel and in concrete were measured. The reference beams failure by flexing with the calculated charges. The bending strengthening proved efficient, increasing the bearing capacity in $44 \%$ and the failure was by shear in the stretch without strengthening. Beams with connectors the increase was higher.
\end{abstract}

Keywords: reforço estrutural, estruturas de concreto armado, interface concreto-graute, conectores.

\section{Resumo}

Este trabalho é relativo a uma investigação experimental sobre reforço à flexão de vigas de concreto armado por encamisamento aplicando-se um tipo de conector metálico na ligação substrato/concreto novo. O programa experimental foi constituído de 5 vigas utilizadas para referência (sem reforço), 5 vigas reforçadas com superfície do substrato de textura escovada e 5 vigas com conectores metálicos colados no substrato. A aplicação de força foi em dois pontos, inicialmente com um carregamento parcial, executou-se o reforço e finalmente foram ensaiadas até a ruptura. O reforço foi composto pelo acréscimo parcial, por graute, nas laterais e fundo da viga e armaduras. A força aplicada, os deslocamentos, as deformações no aço e no concreto foram medidas. As vigas de referência romperam por flexão com cargas próximas às calculadas. $\mathrm{O}$ reforço à flexão mostrou-se eficiente, elevando a capacidade portante em $44 \%$ e a ruptura foi por cisalhamento no trecho sem reforço. Nas vigas com conectores o aumento foi superior.

Palavras-chave: structural strengthening, reinforced concrete structures, concrete-grout interface, connectors. 


\section{Introduction}

Historically, and may still be, the reality of constructions in Brazil shows that the number of structures in reinforced concrete susceptible to rehabilitation increases as they age. When a structure is no longer able to adequately meet its functions, it is necessary to rehabilitate it, that is, to make it capable of satisfying society's demand, at the original or higher level, both from the point of view of durability and resistance (FIB [1]). Often structural elements are damaged by misuse, accident or lack of maintenance, making structural recovery services a common task.

The need for structural strengthening arises when a given structural element or structure is no longer able to withstand the applicant's efforts. It can also be used when there are changes in the use of the building that increase the load and changes in the structural system [2]), due to design and / or construction errors, materials without quality, absence of periodic maintenance, intrinsic and extrinsic thermal variations to concrete and accidents, such as shocks, earthquakes, fires, explosions (Simões [3]). However, for the case of recovery or strengthening, there are complex variables in this type of intervention.

One of the variables is the connection between elements shaped at different ages, being one of the factors that can have serious consequences when not properly analyzed and projected. This linkage, between substrate and new concrete, is determinant for the performance, durability and effectiveness of all structural recovery or strengthening services, therefore it is of fundamental importance to know its influence. The recovery or strengthening project in Brazil does not have standards, according to the research carried out in the ABNT catalog. In addition, recovery and reinforcement services result in high cost and skilled labor is needed.

In the preparation of the strengthening project, the existing structure must be evaluated in advance, which involves the available information on design and construction, inspection and analysis of safety conditions.

It is essential, in strengthening services, the unloading of all weight that can be removed from the structure without affecting it, in order to guarantee the stress transmission to the material used in the reinforcement process. In order to guarantee the efficiency of the reinforcement process, the materials used must have good durability, low permeability, good strength, good adhesion to concrete and steel, low shrinkage, good workability and compatible properties with concrete and steel (Simões [3]). It is also necessary to know the deformability properties, which includes retraction, deformation modulus, thermal expansion coefficient and Poisson's coefficient. Differential deformations between substrate and new concrete can cause stresses at the bond interface, affecting reinforcement durability and stress transferability (Reis [2]). There are several types of flexural strengthening of beams. Some types also provide strengthening against failure by shearing. Strengthening by bonding steel sheets is a technique applied in cases of deficiency in existing reinforcement, but when structural dimensions and concrete quality are adequate. Strengthening by fiber reinforced polymers in general is carried out in elements that require additions in the tension region, but are also used for shear or in columns. There are catalogs and books about this type of strengthening, generally following international standards ( $\mathrm{ACl}$ [4] and FIB [5]).

The strengthening by post-tensioning systems of reinforced concrete beams basically consists of the insertion of requests contrary to those caused by the loads acting on the structure, reducing the deformations and arrows. The introduction of opposing forces can be promoted by the use of struts, wires or rods, being able to increase the strength of the structural element through a vertical component contrary to those caused by external and permanent loads. To this end, diverter devices may be placed between the tendons and the structure to deflect the tendon as required. These devices and their attachment zones have to be designed to transfer the corresponding design actions (FIB [1]). The strengthening by external post-tensioning systems can also reduce cracks and arrow openings, redistribute efforts in beam spans, increase the load bearing capacity of the beams and supply the deficiency of internal reinforcement.

The strength by casing, which was the type used in this research, is applied by adding reinforced concrete / mortar to the elements to be rehabilitated, increasing the cross section or replacing the deteriorated material. Similar tests were performed by Altun [6]. The strength beams are composite pieces, formed by the connection of two concretes of different ages, which have different characteristics. There is an interface between these concretes, or between concrete and grout, which is responsible for the quality of strengthening, promoted by adherence. Such adhesion is necessary to prevent sliding between the parts so that the part works monolithically.

The calculation of the beams strengthening, in the case of cladding can be done based on NBR 6118 [7], considering the stress and deformations existing before it (FIB [1]).

Concrete-concrete bonds, molded at different ages, should be considered as the transfer of stresses through the interfaces, whose main objective is to withstand the shearing stresses. The adhesion between substrate and new concrete is necessary to guarantee the joint behavior of the original part and the strengthening, in order to approach the behavior of a monolithic part ( $\mathrm{ACl}[8])$. The treatment of the bonding surface is fundamental to obtain a satisfactory bond between the substrate and the new concrete, in order to obtain better adherence conditions (FIB [1]). The bonding surface must be rough, free from dust, grease or oil and should be applied for removal of the cement laitance. Tests carried out by Cheong and Macalevey [9] verified the influence of the type of anchorage, the form of anchorage and the amount and type of anchorage of the stirrups.

The main factors that influencing at the interface resistance are concrete strength, contact surface adhesion, contact surface roughness, shearing keys, transversal reinforcement and load type. The mechanisms of stress transfer at the interface can be by frictional, mechanical actions and transversal reinforcement that crosses the interface, called connectors (FIB [1]). The use of connectors in the bonding interface promotes increased resistance to shearing stresses, and the adoption of connectors across the interface between substrate and new concrete is a feature widely used to obtain the monolithic behavior of the reinforced part (FIB [1]). 
The present work aims to verify the influence of steel connectors, positioned between the interface surface between substrate and grout, in the flexural strengthening of beams produced by the increase of the cross section and addition of reinforcements in the tension region.

\section{Materials and experimental program}

\subsection{Experimental program}

The experimental program aimed to evaluate the influence of steel connectors, positioned to the concrete-grout interface surface, designated in this work as interface, in the flexural strengthening of beams produced by the increase of cross section and additional reinforcement. The bonding surface interfaces were smooth without and with steel connectors being used. The contact surfaces were brushed in order to remove the laitance from the cement and increase the roughness. The connectors were fabricated with 10 $\mathrm{mm}$ diameter RC 50 steel bar rests, that is, easy to manufacture. It should be noted that the study has aspects that differ from the existing majority. The first is that in most of the studies the reinforcement is due to insufficient armor, while reinforcement will be carried out for the tensioned and compressed region. Another important aspect is the approximation of the tests to a real situation: in practice one can make a small relief in the actions and the reinforcement is executed with the remaining action acting on the beam and finally it is released for the total action superior to that of the initial design, so it will be simulated in the test.

The experimental program consists of 15 beams distributed in three test series, each series consisting of 5 beams, identified from 1 to 5 . A series of 5 beams used for reference (VRef), without any reinforcement, 5 reinforced beams with smooth interface substrate $(\mathrm{VL})$ and 5 reinforced beams with substrate surface containing bonded steel connectors (VC).

The reference beams, called VRef, were $200 \mathrm{~cm}$ long, span from $180 \mathrm{~cm}$, rectangular cross section with $12 \mathrm{~cm}$ wide by $22 \mathrm{~cm}$ high and $3 \mathrm{~cm}$ cover.

The reinforcement on the beams with smooth interface surface, with and without connectors, was performed by adding SikaGrout $\AA$
250 grout, in the sides and bottom section in a length of $140 \mathrm{~cm}$. The steel connectors were positioned vertically using the Sikadur ${ }^{\circledR}$ Epoxy, spaced every $10 \mathrm{~cm}$. The bonding of the connectors occurred with the beam in pre-loading condition.

Self-compacting concrete, with a compressive strength of $20 \mathrm{MPa}$, was used in the reference beams. For the reinforcement of the reference beams, $2 \varnothing 12,5 \mathrm{~mm}$ were used in the bottom longitudinal reinforcement and $2 \varnothing 5 \mathrm{~mm}$ for the upper longitudinal reinforcement, that had the sole function of carrying of stirrups. The stirrups were $\varnothing 5 \mathrm{~mm}$, spaced every $10 \mathrm{~cm}$. The beams were subjected to four points bending test, distant of $60 \mathrm{~cm}$ of the supports.

\subsection{Calculations for the reference beam}

The design of the beams was done in such a way that the " $x$ " value was $40 \%$ of the useful height of the beam and that failure by tension in the flexion, with yield stress of the longitudinal reinforcement and crushing of the compressed concrete. To determine the useful height, it was considered that the longitudinal reinforcement would have a diameter of $12.5 \mathrm{~mm}$, the stirrups $5 \mathrm{~mm}$ and the cover of 3.0 $\mathrm{cm}$, resulting in a useful height of $17.875 \mathrm{~cm}$. The bending moment of calculation, for these conditions, supported by the beam was obtained through Equation 1.

$M_{d}=0,68 \cdot f_{c d} \cdot b_{w} \cdot x \cdot(d-0,4 \cdot x)$

Where: $M_{d}$ is the design bending moment, $f_{c d}$ is the design value of cylinder compressive strength of concrete, $b_{w}$ is the breadth of web, $x$ is depth of compression zone and dd is the effective depth to main tension reinforcement.

Adopting the weighting coefficient of the concrete strength of 1.4, resulted in a bending moment of $12.51 \mathrm{kN} \times \mathrm{m}$. The necessary flexural longitudinal reinforcement was obtained by applying Equation 2, which resulted in a steel area of $1.92 \mathrm{~cm}^{2}$.

$A_{s}=\frac{M_{d}}{f_{y d^{*}}(d-0,4 . x)}$

Where: $A_{s}$ is the area of reinforcement, $f_{y d}=43.48 \mathrm{kN} / \mathrm{cm}^{2}$ is the design yield strength of reinforcing steel in tension.

With the adopted tension reinforcement bars of $2 \varnothing 12,5 \mathrm{~mm}$, the " $x$ "

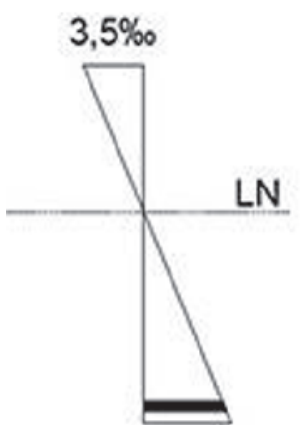

$3,333 \%$

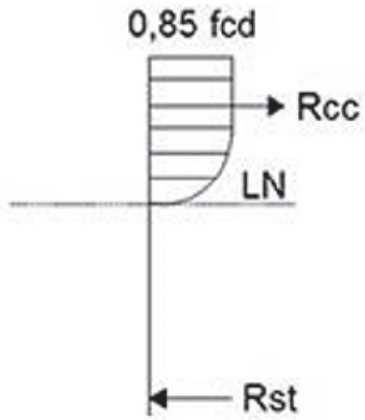

(a) Tension and strain state $-100 \%$ Load

Figure 1

Tension and deformation states in the reference section

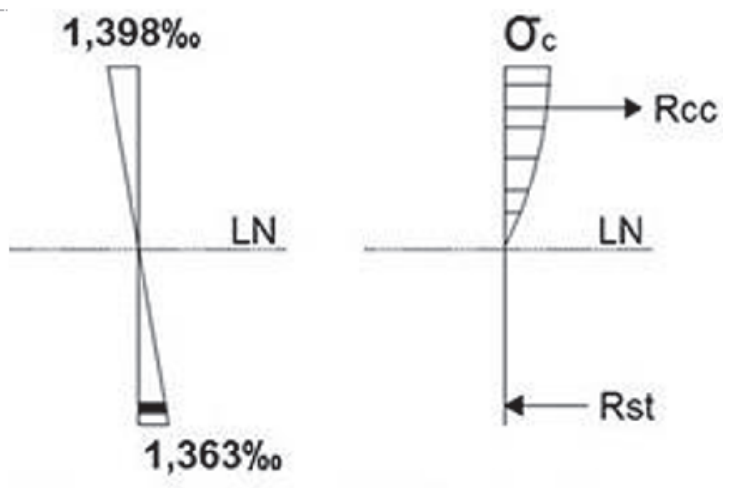

(b) Tension and strain state $-80 \%$ Load 


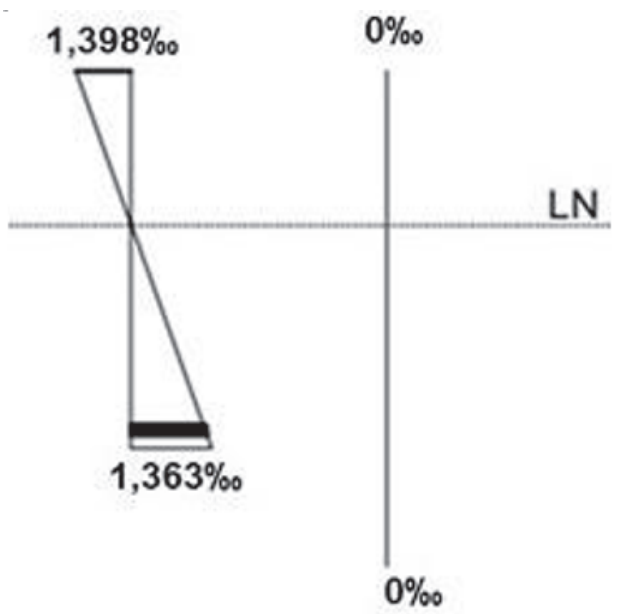

(a) Strain state $-80 \%$ Load

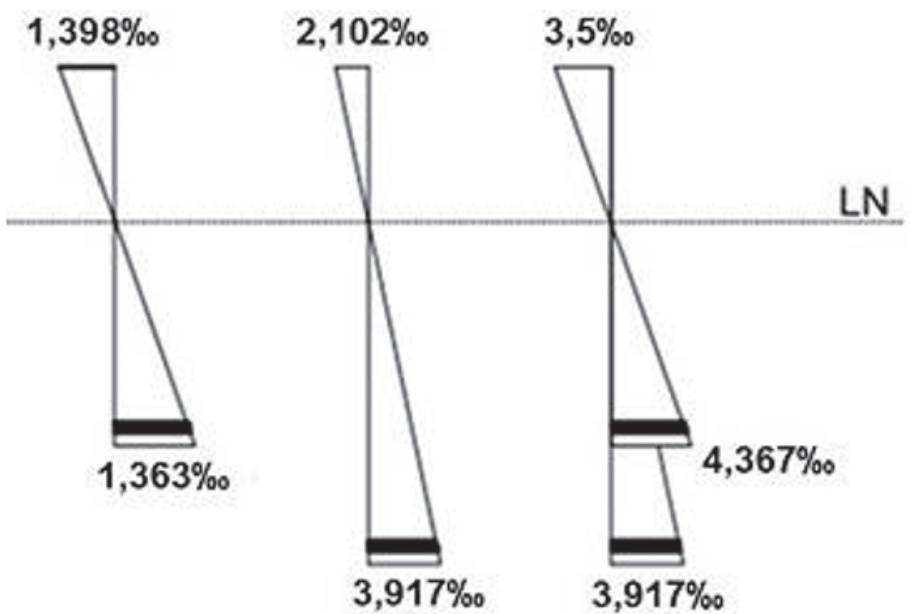

(b) Strain state - Maximum project load $(87,70 \mathrm{kN})$

Figure 2

Reinforced section strain state

change from $0.4 \times d$ to $0.513 \times d$, increasing the bending moment of calculation to $15.16 \mathrm{kN} \times \mathrm{m}$. In order to reach this calculation bending moment, considering that the beam weight itself produces a bending moment of calculation of $0.33 \mathrm{kN} \times \mathrm{m}$, the total $\mathrm{Fd}$ load to be applied is $49.45 \mathrm{kN}$. This value was obtained considering the coefficients of NBR 8681 [9], but as the load will be controlled and with a small variation a smaller coefficient was adopted so the design load considered $100 \%$ will be $42.5 \mathrm{kN}$.

Figure 1 shows the stress and strain states of the reference beam section with $100 \%$ and $80 \%$ of the permanent load acting on the beams. The stress in the concrete for the section submitted to $80 \%$ of the load was obtained according to item 8.2.10.1 of NBR 6118 [7]. The transversal reinforcement design was done by adopting the calculation model I of NBR 6118 [7], which allows compression diagonals inclined to $45^{\circ}$ in relation to the longitudinal axis of the structural element and that the portion of shearing force resisted by mechanisms complementary to the lattice model has a constant value. The shear reinforcement was obtained through Equation 3.

$A_{s w}=\frac{V_{s w}}{0,9 . d . f_{y w d}}$

Where: $A_{\mathrm{sw}}$ : area of shear reinforcement; $V_{\mathrm{sw}}$ : resistance of reinforcement to shear force; dd: effective depth to main tension reinforcement; $\mathrm{f}_{\mathrm{ywd}}$ : design yield strength of stirrups steel in tension. Considering the calculation force in the design of $49.45 \mathrm{kN}$ and the self weight, the shearing produced will be $25.56 \mathrm{kN}$. The portion of shearing force absorbed by mechanisms complementary to that of the lattice $\left(\mathrm{V}_{\mathrm{co}}\right)$ is $14.22 \mathrm{kN}$. Using the stirrups of $\varnothing 5.0 \mathrm{~mm}$, the calculated area of shear reinforcement is $1.615 \mathrm{~cm}^{2} / \mathrm{m}$, therefore, $\varnothing 5.0 \mathrm{~mm}$ stirrups spaced $24 \mathrm{~cm}$. Due to the maximum spacing allowed, $\varnothing 5.0 \mathrm{~mm}$ stirrups spaced $10 \mathrm{~cm}$, was used. The use of these stirrups allows the beam to be subjected to a shearing of up to $41.69 \mathrm{kN}$, being $14.22 \mathrm{kN}$ of the $\mathrm{V}_{c 0}$ and $27.47 \mathrm{kN}$ of the resistance of reinforcement $\left(V_{s w}\right)$. The total force $F_{d}$, discounted from the calculated shear produced by the self weight of $0.83 \mathrm{kN}$, may be $81.72 \mathrm{kN}$ applied to the beam, i.e., $40.86 \mathrm{kN}$ per point.

\subsection{Calculations for the reinforced beam}

The reference beam executed has its ability to resist flexural moment at $15.16 \mathrm{kN} \times \mathrm{m}$ and $81.72 \mathrm{kN}$ for shear. As the reinforcement will not be for shearing, it was initially calculated for the applied calculation load of $81.72 \mathrm{kN}$, thus a total bending moment of calculation of $24.90 \mathrm{kN} \times \mathrm{m}$.

The original beam section, after having reduced the weight, has not behavior at Ultimate Limit State (ULS), and the new position of the " $x$ " was obtained through the equations of static equilibrium and deformations. In Figure 2, deformation conditions of the section of the original beam with load $F_{d}=49.45 \mathrm{kN}$ (ULS) or $F_{k}=35.32 \mathrm{kN}$ and for the maximum design load after the reinforcement $(87.70 \mathrm{kN})$ are shown, indicating that the failure is likely to occur by shearing. The tension in the concrete for the section submitted to $80 \%$ of the design load (34 kN) was obtained according to item 8.2.10.1 of NBR 6118 [7]. The tension in the grout was obtained according to item 8.2.10.1 of NBR 6118 [7], adopting behavior like concrete, as it is cementitious material. A reduction factor of 0.85 (Rüsch effect) was adopted to obtain the grout tension due to the lack of knowledge about this effect in the material.

From the static equilibrium equations, considering grout with a compressive strength of $50 \mathrm{MPa}$, a steel area of 2,122 $\mathrm{cm}^{2}$ was obtained for reinforcement. Due to the need for bonding of strain gauges on the bars, it was decided to place $2 \varnothing 12.5 \mathrm{~mm}$. With this steel reinforcement and grout, the area will have a durable bending moment of $37.16 \mathrm{kN} \times \mathrm{m}$. To achieve this bending moment an applied characteristic load of $87.70 \mathrm{kN}$ is required, indicating that the failure to occur by shearing.

Therefore, the reinforcements were $2 \varnothing 12.5 \mathrm{~mm}$ in the lower longitudinal part and $2 \varnothing 5.0 \mathrm{~mm}$ in the upper longitudinal part. The transverse reinforcement were $\varnothing 5.0 \mathrm{~mm}$, spaced every $10 \mathrm{~cm}$. 


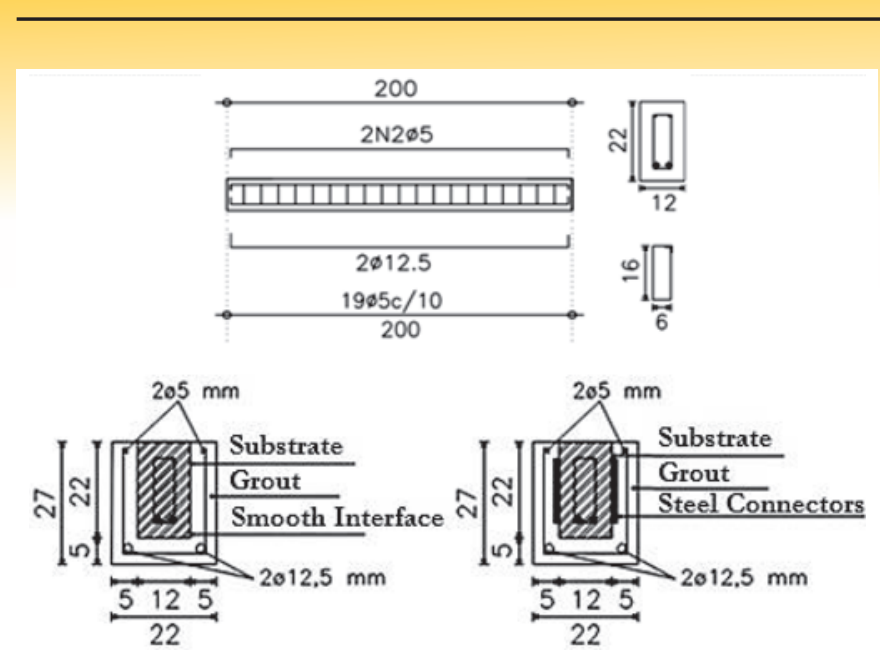

Figure 3

Beam geometry and frame information

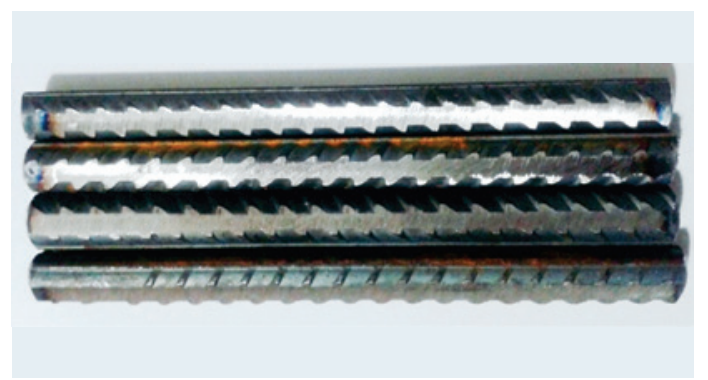

Figure 4

a) Connectors (front)
The values presented for the resistant bending moments contemplate the safety criteria used by the norms and consider that there will be the perfect connection between the concrete and the grout. In this way, the values obtained in the tests are expected to be higher. The geometry and reinforcement information of the strengthened beams are shown in Figure 3.

\subsection{Steel connectors}

The steel connectors were placed in view of a possible partial failure in the bond between concrete and grout. Simple connectors were designed and can be made with common construction steel bars. Thus, they were produced using steel bars of $\varnothing 10 \mathrm{~mm}$, having 15 $\mathrm{cm}$ of length, being in part of the surface were removed area of the doughs for bonding in the substrate. They were positioned to the partially loaded beams and, later, the reinforcing, the formworks and the grout were placed (Figure 4).

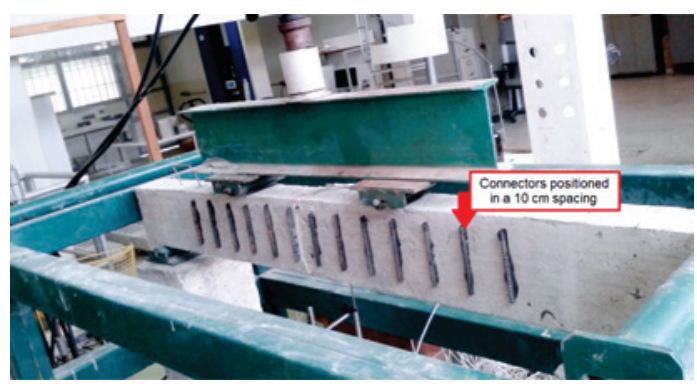

b) Connectors positioned in a10 $\mathrm{cm}$ spacing

Details of the connectors

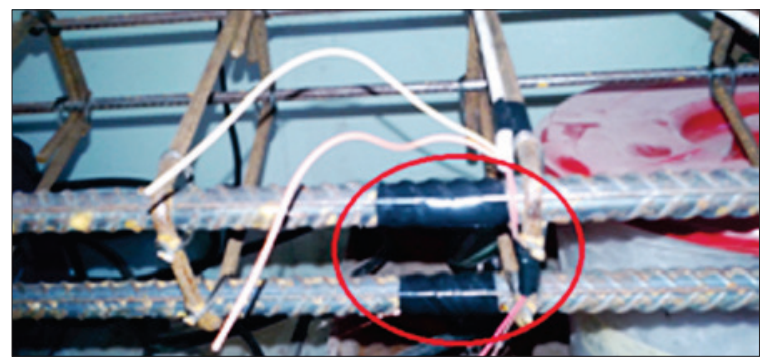

a) Extensometers attached to the central part of the longitudinal tension reinforcement of the original beam

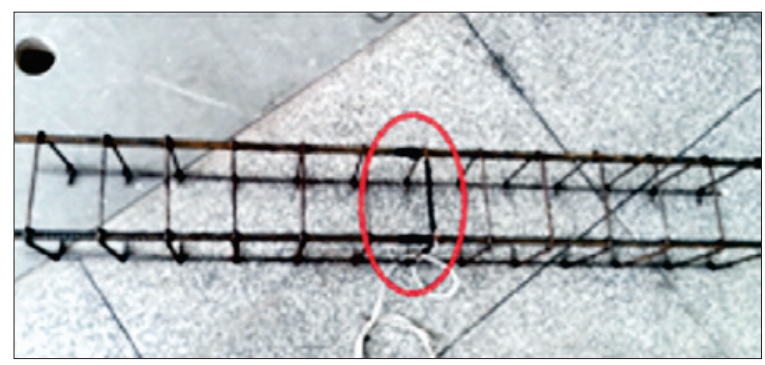

c) Extensometers attached in the central part of the longitudinal tension reinforcement

Figure 5

Schematic of the localization of the extensometers

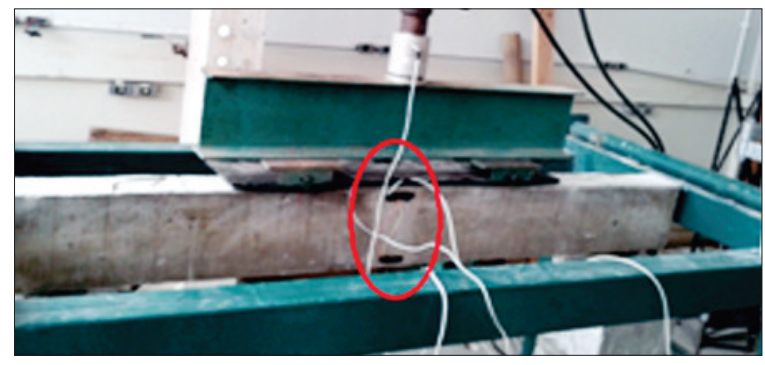

b) Extensometers attached to the sides of the original beam (region tensioned and compressed)

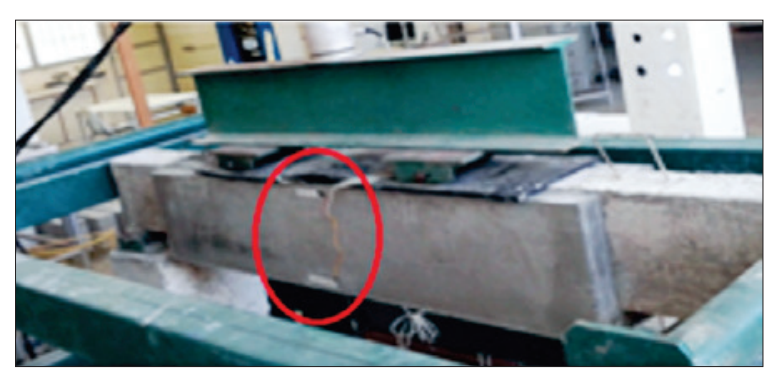

d) Extensometers attached on the sides of the reinforcement (region tensioned and compressed) 
Table 1

Concrete information for the beams

\begin{tabular}{|c|c|c|c|c|c|c|}
\hline $\begin{array}{c}\text { Age } \\
\text { (days) }\end{array}$ & $\begin{array}{c}\text { Strenght } \\
\text { to average- } \\
\text { compression } \\
(\mathrm{MPa})\end{array}$ & $\begin{array}{c}\text { Standard } \\
\text { deviation } \\
(\mathrm{MPa})\end{array}$ & $\begin{array}{c}\text { Coefficient } \\
\text { of variation } \\
\%\end{array}$ & $\begin{array}{c}\text { Average modulus } \\
\text { of elasticity } \\
\text { (GPa) }\end{array}$ & $\begin{array}{c}\text { Standard } \\
\text { variation } \\
(\mathrm{GPa})\end{array}$ & $\begin{array}{c}\text { Coefficient } \\
\text { of variation } \\
\%\end{array}$ \\
\hline 7 & 12,85 & 1,56 & 12,14 & - & - & - \\
\hline 28 & 21,99 & 0,04 & 0,18 & 19,89 & 1,03 & 5,18 \\
\hline
\end{tabular}

\subsection{Strain gage position}

The strain measure in the steel were obtained through uniaxial resistance strain gages with a length of 0.250 ". In the concrete were uniaxial with length of 1,000 ", both with gage resistance of 120 Ohms. A linear displacement measuring device, was used, and the structural behavior of the beams during the tests was recorded through a data acquisition system. Previously, the strain gages were fixed in the reinforcement and in the concrete after cast of the reference beam. After the partial loading and strengthening, the strain were fixed in the grout, as indicated in Figure 5.

\subsection{Force application program and results}

The experimental system was four point bending test, distance load-supports of $60 \mathrm{~cm}$, according to Figure 6 . The beams, before being reinforced, were loaded with total design load until the stabilization of the displacement. For the strengthening service, the beams were partially discharged, remaining $80 \%$ of the load (34 kN), considering a $20 \%$ relief of the accidental load for the structure.

The strengthened beams were submitted to the total design load and later until the failure, after completing the strengthening and waiting 24 hours to achieve resistance of the grout.

\section{Results and discussions}

The compressive strength of concrete at 7 days, 28 days, essay's day and the modulus of elasticity, obtained according to NBR 5739 [11] and NBR 8522 [12], respectively, are shown in Table 1.

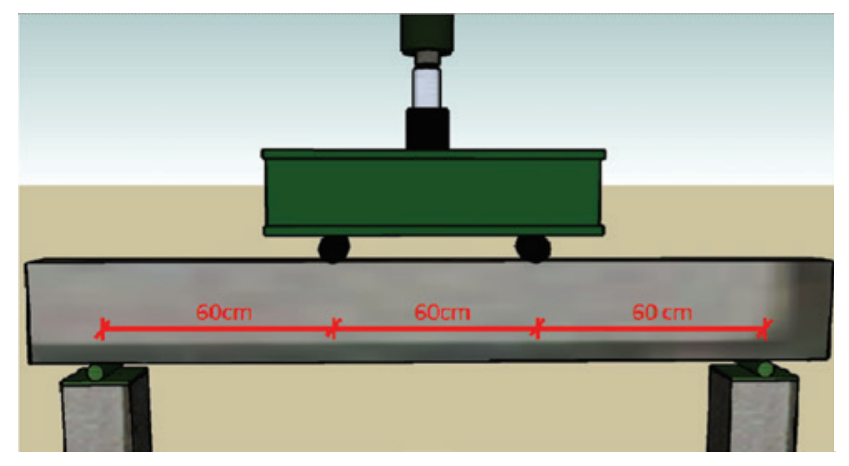

a) Beams without reinforcement
The tests of the steel bars were carried out according to NBR 7480 [13]. The results obtained are shown in Table 2.

\subsection{Reference beams}

The compressive strength of concrete was $22.78 \mathrm{MPa}$ and modulus of elasticity of $27.04 \mathrm{GPa}$, at the time of the tests of the reference beams. It is verified that the modulus of elasticity reached the value compatible with the estimated by the NBR 6118 [7] equation.

Initial crack due to flexion occurred in 4 reference beams (V2Ref to V5Ref) and V1Ref presented initial shearing crack. All the beams failed due to flexion. In the Figure 7 are showed the characteristic cracks in the center of the reference beams. Table 3 shows the results obtained during the tests of the reference beams.

The structural behavior of the reference beams during the tests have made it possible to verify that:

- The first cracks in the beams appeared with an average load of $65.14 \mathrm{kN}$, except the V4Ref that obtained the first crack, due to flexion, with a load of $54.7 \mathrm{kN}$. Considering all the loads when the first crack appeared, the average load was $63.05 \mathrm{kN}$.

- The failure loads of the beams were close, obtaining an average failure load of $72.15 \mathrm{kN}$ and a standard deviation of $1,712 \mathrm{kN}$. The coefficient of variation - CoV of $2.37 \%$ - indicates uniformity

\section{Table 2}

Mechanical properties of steel

\begin{tabular}{|c|c|c|c|}
\hline $\begin{array}{c}\text { Diameter } \\
(\mathrm{mm})\end{array}$ & $\begin{array}{c}\text { Yield stress } \\
(\mathrm{MPa})\end{array}$ & $\begin{array}{c}\text { Average } \\
\text { failure tension } \\
(\mathrm{MPa})\end{array}$ & $\begin{array}{c}\text { Average } \\
\text { stretching } \\
\text { in 10ø }\end{array}$ \\
\hline 12,5 & 601 & 719 & 11,73 \\
\hline
\end{tabular}

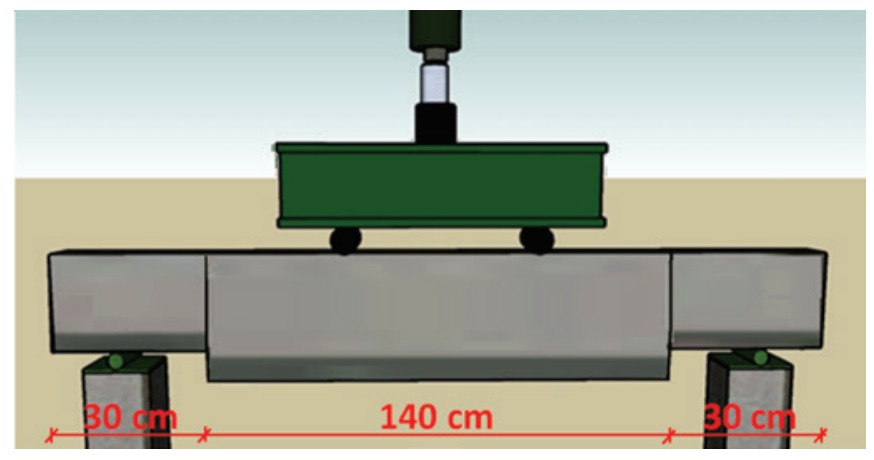

b) Reinforced beams

Figure 6

Test pattern of the beams 


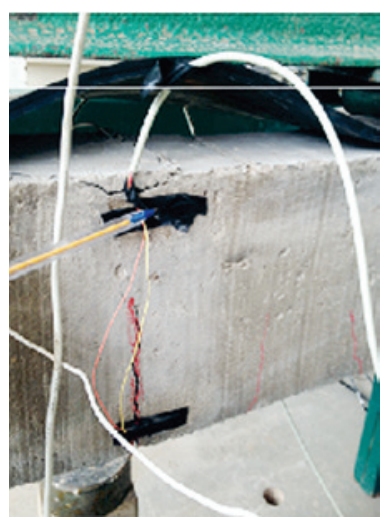

a) V1Ref

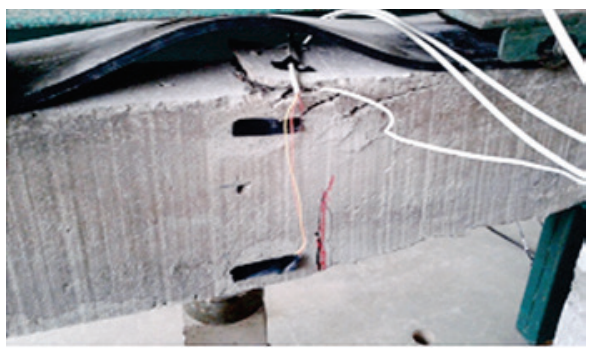

b) V2Ref

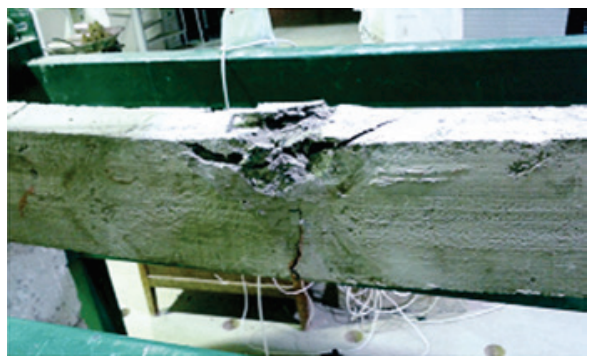

d) V4Ref

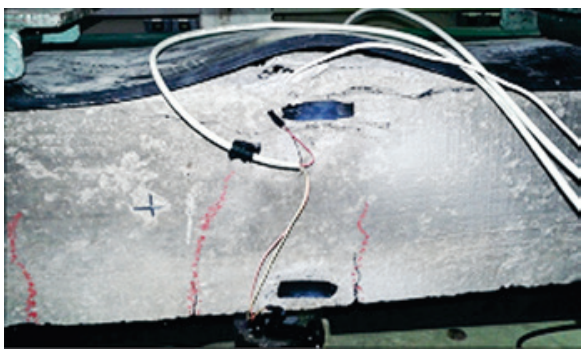

c) V3Ref

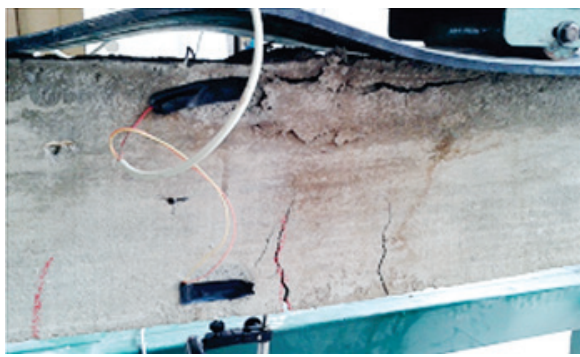

e) V5Ref

Figure 7

View of the central part of the reference beams broken by flexion

\section{Table 3}

Results of reference beams

\begin{tabular}{|c|c|c|c|c|c|c|c|c|}
\hline \multirow[b]{2}{*}{ Beams } & \multirow[b]{2}{*}{$\begin{array}{c}1^{a} \text { crack } \\
(\mathrm{kN})\end{array}$} & \multirow[b]{2}{*}{$\begin{array}{l}\text { Type of } \\
\text { crack }\end{array}$} & \multirow[b]{2}{*}{$\begin{array}{l}\text { Displacement } \\
100 \% \text { load } \\
(\mathrm{mm})\end{array}$} & \multicolumn{5}{|c|}{ Failure } \\
\hline & & & & $\begin{array}{l}\text { Displacement } \\
(\mathrm{mm})\end{array}$ & $\begin{array}{l}\text { Load } \\
(\mathrm{kN})\end{array}$ & $\begin{array}{c}\text { Average } \\
\text { load } \\
(\mathrm{kN})\end{array}$ & $\begin{array}{l}\text { Standard } \\
\text { deviation } \\
(\mathrm{kN})\end{array}$ & $\begin{array}{c}\text { Coefficient } \\
\text { of variation } \\
\%\end{array}$ \\
\hline V1Ref & 65,00 & Shearing & 6,16 & 17,95 & 74,36 & \multirow{5}{*}{72,15} & \multirow{5}{*}{1,712} & \multirow{5}{*}{2,37} \\
\hline V2Ref & 68,27 & Flexion & 6,32 & 12,32 & 71,87 & & & \\
\hline V3Ref & 62,30 & Flexion & 6,02 & 13,75 & 73,34 & & & \\
\hline V4Ref & 54,70 & Flexion & 6,81 & 12,31 & 70,08 & & & \\
\hline V5Ref & 65,00 & Flexion & 5,49 & 13,27 & 71,12 & & & \\
\hline
\end{tabular}

in the behavior of the beams, therefore it can be considered that, for comparative effect, the results are consistent.

- Considering the concrete strength of $22.78 \mathrm{MPa}$, obtained at the test date, the calculated failure load in which the coefficients equal to 1 were considered, increases from $49.45 \mathrm{kN}$ to 73.83 $\mathrm{kN}$, which was close of the average failure load obtained during the tests $(72.15 \mathrm{kN})$.

- Analyzing the load-displacement ratio, it was possible to verify that the vertical displacements for all the tests were very close, with an average of $6.16 \mathrm{~mm}$, when the applied load of the design was analyzed, being the standard deviation of the displacements obtained for $100 \%$ of the load of applied equal to $0.478 \mathrm{~mm}$, resulting in a CoV of $7.77 \%$. At disruption, vertical displacements averaged $13.92 \mathrm{~mm}$ and CoV was $16.79 \%$.

- The average steel strain obtained for $100 \%$ of the load was $1.878 \%$ and for $80 \%$ of the load was $1.538 \%$. The calculated deformation considering $100 \%$ of the design load was 3,333 \%o and for $80 \%$ of the design load was $1.363 \%$.
- The average strain on the compressed face of the concrete obtained for $100 \%$ of the load was $0.7146 \%$ and for $80 \%$ of the load was $0.6359 \%$. The strain considered for $100 \%$ of the design load was $3.5 \%$ and for $80 \%$ of the design load was $1.398 \%$.

- Considering all the reference beams, the average strain in the compressed face of concrete obtained at the instant of failure was $1,764 \%$. The V1Ref suffered a much greater strain, when compared to the others, presenting deformation of $2,649 \%$, being the only reference beam that cracked due to shearing.

\subsection{Reinforced beams without connectors}

At the time of the tests of the beams without connectors, the substrate concrete and the grout had the characteristics described in Table 4.

Due to the time between the tests of the beams being approximately 30 hours, 4 cylindrical specimens were used to determine the compressive strength and modulus of elasticity of the concrete 
Table 4

Material information at the time of the test - beams with smooth interface without connectors

\begin{tabular}{|c|c|c|c|c|}
\hline Beam & $\begin{array}{c}\text { Substrate strenght } \\
\text { (MPa) }\end{array}$ & $\begin{array}{c}\text { Substrate modulus } \\
\text { of elasticity } \\
\text { (GPa) }\end{array}$ & $\begin{array}{c}\text { Grout resistence } \\
\text { (MPa) }\end{array}$ & $\begin{array}{c}\text { Grout modulus } \\
\text { of elasticity } \\
\text { (GPa) }\end{array}$ \\
\hline VL1 & 23,61 & 24,15 & 33,26 & 29,24 \\
\hline VL2 & 23,61 & 24,15 & 34,09 & 29,45 \\
\hline VL3 & 23,16 & 24,73 & 32,18 & 29,20 \\
\hline VL4 & 23,16 & 24,73 & 23,90 & 23,60 \\
\hline VL5 & 21,05 & 24,13 & 26,30 & 26,50 \\
\hline
\end{tabular}

substrate for each 2 beams. For the grout, the determination of the compressive strength and modulus of elasticity was performed for each beam tested. All these tests followed the procedures of the standards of NBR 5739 [11] and NBR 8522 [12], respectively.

Of the 5 beams with smooth surface without tested connectors, only VL1 presented flexural cracking during preloading, and the appearance of the crack at $44.98 \mathrm{kN}$. Figure 8 shows the characteristic cracks in reinforced beams without connectors. Table 5 shows the results of the displacement, the failure loads, and the types of cracks obtained for the smooth interface beams without connectors.

Analyzing the results obtained during the tests it is possible to verify that:

- The first cracks, after the beams reinforcement service, appeared with a mean load of $68.60 \mathrm{kN}$, standard deviation of $13.61 \mathrm{kN}(\mathrm{CoV}=19.84 \%)$.

- None of the reinforced beams showed cracking due to grout's tension.

- The average load of the strengthened beams with smooth interface without connectors was $104.08 \mathrm{kN}$, with a standard deviation of $8.77 \mathrm{kN}(\mathrm{CoV}=8.37 \%)$.

- Analyzing the displacement of the beams at the failure, it was possible to verify that the values were very close, being 12.9 $\mathrm{mm}$ the average obtained for the displacement, in which it obtained a standard deviation of $1.52 \mathrm{~mm}$ (CoV of $11.78 \%$ ).

- All the beams had pre-cracking due to shear and were subjected to failure by shearing of the substrate, varying due to crack and grout detachment.

- The beam VL4 showed a significant deviation in the strain analisys in the longitudinal tension reinforcement, but after this reading it returned to a number closer to the previous ones. The same beam (VL4) also presented a reading that indicated that the upper face of the concrete of the substrate after the reinforcement service was alleviated, generating a smaller strain for the higher tensions.

- The average strain in the longitudinal tension reinforcement of the substrate at the moment of failure was $2.089 \%$, with a standard deviation of $0.535 \%$ ( $\mathrm{CoV}=25.61 \%)$.

- The average strain in the compressed face of the grout obtained at the moment of failure was of $0.449 \%$, presenting a standard deviation of $0.130 \%$ and for the longitudinal tensile reinforcement of the reinforcement the average strain obtained at the moment of failure was of $1.317 \%$. It should be noted that the deformation of VL1, VL2 and VL5 was considered for the calculation of the mean strain for the tension reinforcement, considering that for the other beams the data acquisition did not record the values for these deformations. The VL1 presented a lower deformation value for both the grout and the tension reinforcement, when compared to the others, presenting deformation of $0.246 \%$ for the grout and $1,000 \%$ for the reinforcement. Therefore, the reinforcement for this beam was the one that least supported the increase of load, and the failure occurred with the lowest load

\section{Table 5}

Results of beams with smooth interface without connectors

\begin{tabular}{|c|c|c|c|c|c|c|}
\hline \multirow[b]{2}{*}{ Beams } & \multirow{2}{*}{$\begin{array}{l}\text { Load } 1^{\text {st }} \\
\text { crack after } \\
\text { strengthening } \\
(\mathrm{kN}) / \text { type } \\
\text { of failure }\end{array}$} & \multicolumn{3}{|c|}{ Arrow $(\mathrm{mm})$} & \multirow[b]{2}{*}{$\begin{array}{l}\text { Failure load } \\
\qquad(\mathrm{kN})\end{array}$} & \multirow[b]{2}{*}{ Failure type } \\
\hline & & $80 \%$ load & $100 \%$ load & Failure & & \\
\hline VL1 & 85,61 / shearing & 7,00 & 7,10 & 10,87 & 90,87 & $\begin{array}{l}\text { Substrate shearing / } \\
\text { grout detachment }\end{array}$ \\
\hline VL2 & 70,64 / shearing & 6,32 & 6,84 & 13,37 & 102,03 & $\begin{array}{c}\text { Substrate shearing / grout } \\
\text { rupture and detachment }\end{array}$ \\
\hline VL3 & 53,80 / shearing & 6,64 & 7,23 & 12,96 & 113,01 & $\begin{array}{l}\text { Substrate shearing / grout } \\
\text { rupture and detachment }\end{array}$ \\
\hline VL4 & 76,99 / shearing & 6,80 & 6,98 & 15,03 & 103,42 & $\begin{array}{l}\text { Substrate shearing / } \\
\text { grout rupture }\end{array}$ \\
\hline VL5 & 56,00 / shearing & 6,38 & 7,21 & 12,27 & 111,09 & $\begin{array}{l}\text { Substrate shearing / grout } \\
\text { rupture and detachment }\end{array}$ \\
\hline
\end{tabular}


applied in relation to the other strengthened beams with surface of the smooth interface.

The strain values for reinforced beams with smooth interface without connectors are listed in Table 6.

\subsection{Strengthened beams with connectors}

In performing the tests of the beams with smooth interface surface with bonded steel connectors, the substrate concrete and the grout presented the characteristics described in Table 7.

The intervals between the beams tests were also approximately 30 hours, like beams without connectors. The compressive strength and modulus of elasticity of the concrete substrate were determined. In the same way these characteristics were

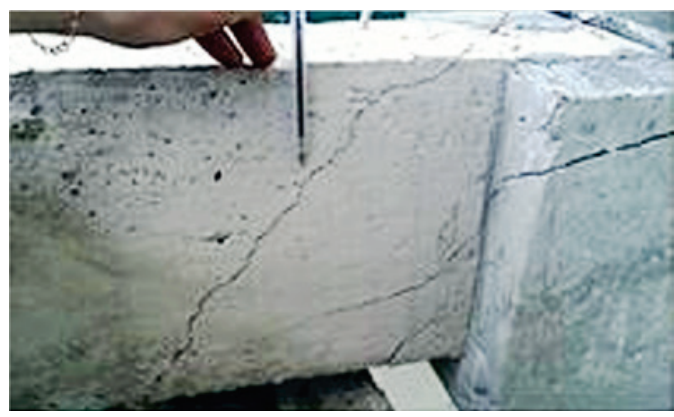

a) Substrate crack due to shearing

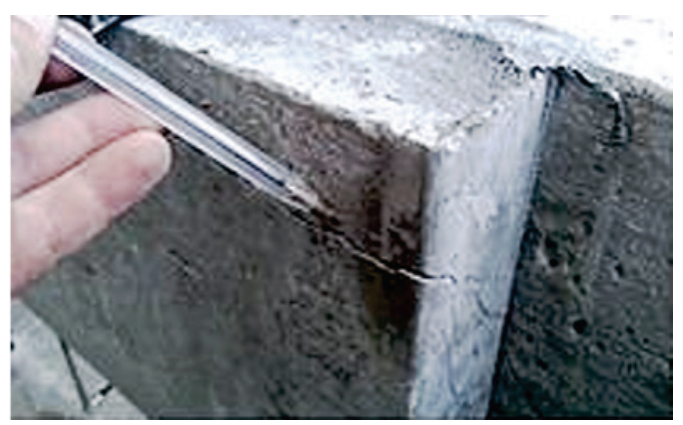

c) Grout rupture

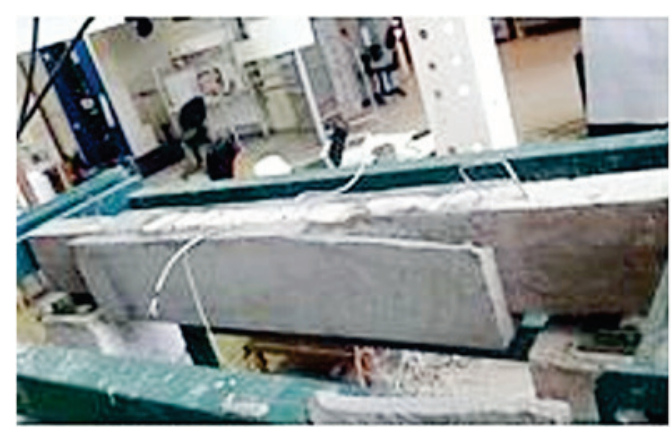

e) Final aspect of the beam (left side view) determined to the grout, for each beam tested. These tests also followed the procedures of the norms of NBR 5739 [11] and NBR 8522 [12], respectively.

Two beams with steel connectors, VC3 and VC5, showed flexural cracks during preloading. The cracks appears when the loads $43.31 \mathrm{kN}$ and $43.29 \mathrm{kN}$ were applied, respectively. Figure 9 shows the characteristic cracks in the beams reinforced with connectors.

- The results of the displacement, failure loads and type of failure obtained for the beams with bonded steel connectors are presented in Table 8 , and it can be verified that: The first cracks, after the beams strengthening service, appeared with an application of average load of $76.37 \mathrm{kN}$, with a standard deviation of $4.69 \mathrm{kN}$, presenting for most of the beams tested values higher than the beams that did not have the steel

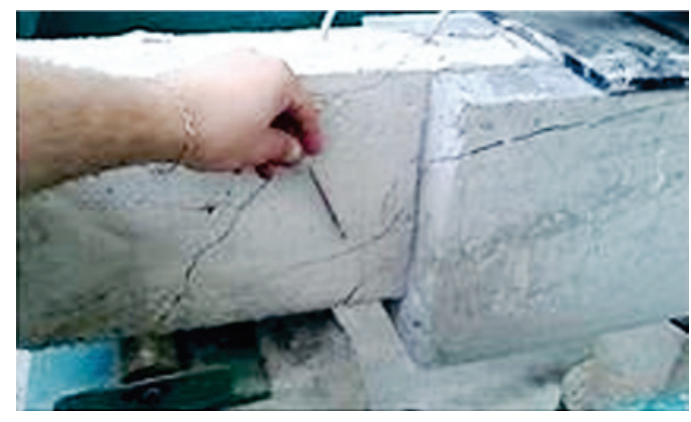

b) Beam support crack due to shearing

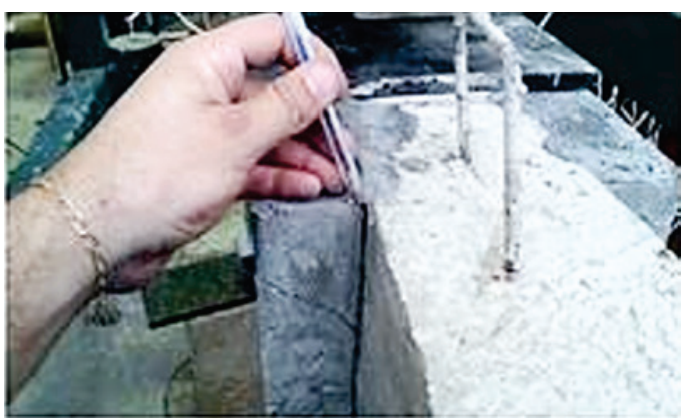

d) Grout detachment

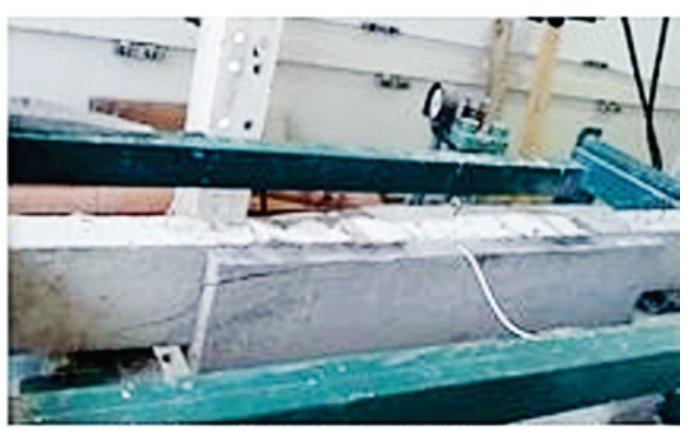

f) Final aspect of the beam (right side view)

Figure 8

Details of VL3 after test 
connectors bonded. From this result it is possible to verify that the bonded steel connector contributes, even with a small portion, to the shearing strength.

- None of the beams tested showed flexural cracks in the reinforcement.
- The average failure load of the strengthening beams with bonded steel connectors was $106.10 \mathrm{kN}$, with a standard deviation of $6.04 \mathrm{kN}$.

- Analyzing the displacement of the beams in the failure, it was possible to verify that the values were close, being $12.82 \mathrm{~mm}$

\section{Table 6}

Strains of the constituent elements of the beams at the moment of failure

\begin{tabular}{|c|c|c|c|c|}
\hline Beams & $\begin{array}{c}\text { Concrete substrate } \\
\text { top surface } \\
(\% \circ)\end{array}$ & $\begin{array}{c}\text { Longitudinal tension } \\
\text { steel of the subtrate } \\
(\%)\end{array}$ & $\begin{array}{c}\text { Grout top surface } \\
\text { (\%) }\end{array}$ & $\begin{array}{c}\text { Longitudinal tension } \\
\text { of reinforcement } \\
(\% \circ)\end{array}$ \\
\hline VL1 & 0,611 & 1,844 & 0,246 & 1,000 \\
\hline VL2 & 0,986 & 1,531 & 0,428 & 1,572 \\
\hline VL3 & 0,259 & 2,565 & 0,539 & $X$ \\
\hline VL4 & 0,042 & 2,751 & 0,449 & $X$ \\
\hline VL5 & 0,997 & 1,752 & 0,583 & 1,378 \\
\hline
\end{tabular}

\section{Table 7}

Material information at the time of the test - beams with connectors

\begin{tabular}{|c|c|c|c|c|}
\hline Beams & $\begin{array}{c}\text { Substrate strength } \\
(\mathbf{M P a})\end{array}$ & $\begin{array}{c}\text { Substrate modulus } \\
(\mathbf{G P a})\end{array}$ & $\begin{array}{c}\text { Grout strength } \\
(\mathbf{M P a})\end{array}$ & $\begin{array}{c}\text { Grout modulus } \\
(\mathbf{G P a})\end{array}$ \\
\hline VC1 & 21,05 & 24,13 & 27,90 & 23,80 \\
\hline VC2 & 24,07 & 22,76 & 23,27 & 26,37 \\
\hline VC3 & 24,07 & 22,76 & 21,68 & 25,21 \\
\hline VC4 & 23,00 & 22,94 & 16,94 & 24,85 \\
\hline VC5 & 23,00 & 22,94 & 23,72 & 26,99 \\
\hline
\end{tabular}

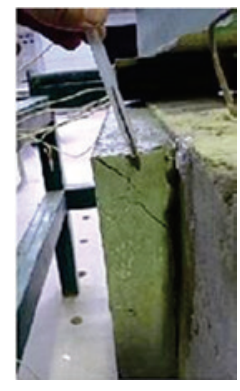

a) Grout rupture

Right support/right surface

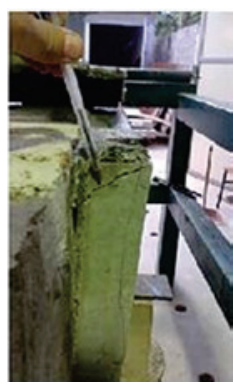

d) Grout rupture

Right support/left surface

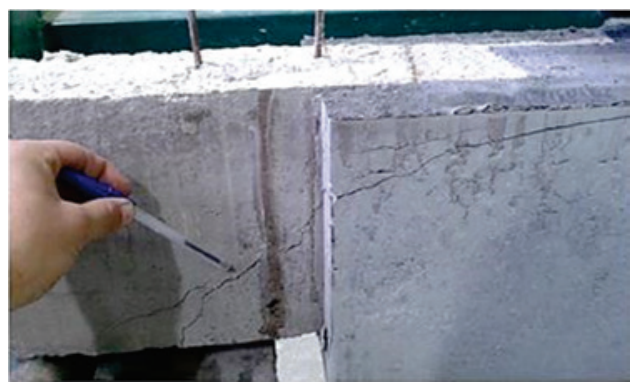

b) Rupture by shearing

Right support/left surface

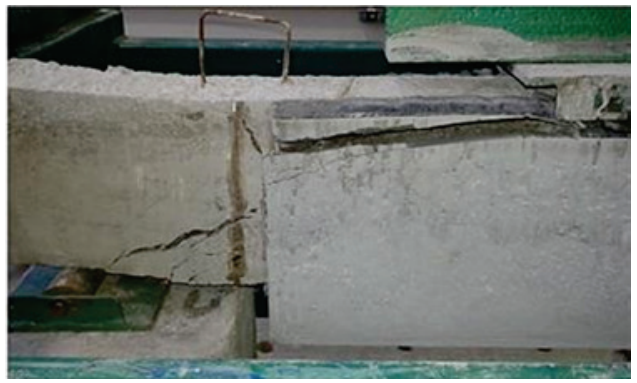

e) Beam rupture by shearing Left support/right surface

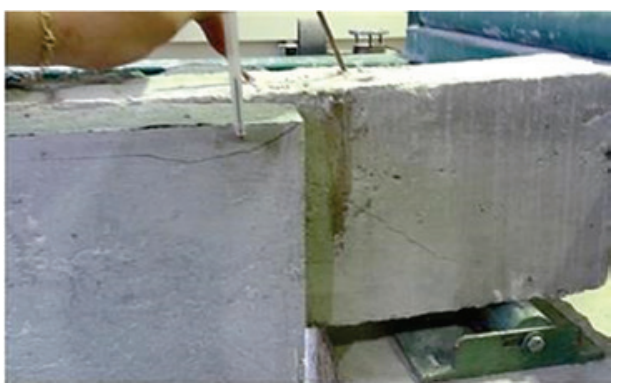

c) Rupture by shearing Right support/right surface

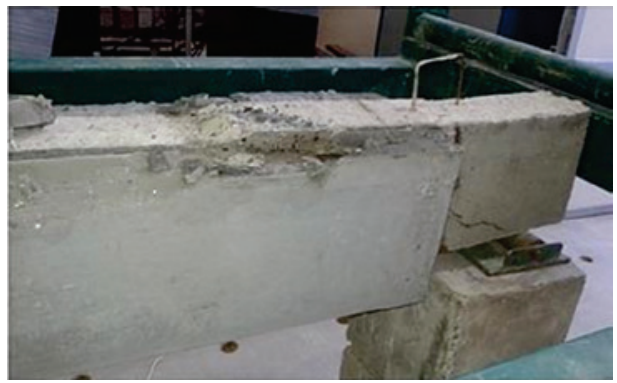

f) Final aspect of the beam after rupture Left support/left surface

\section{Figure 9}

Details of VC4 after test 
Table 8

Results of the beams with positioned steel connectors

\begin{tabular}{|c|c|c|c|c|c|c|}
\hline \multirow[b]{2}{*}{ Beams } & \multirow{2}{*}{$\begin{array}{l}\text { Load } 1^{\text {st }} \\
\text { crack after } \\
\text { reinforcement } \\
(\mathrm{kN}) / \text { type } \\
\text { of failure }\end{array}$} & \multicolumn{3}{|c|}{ Displacement (mm) } & \multirow[b]{2}{*}{$\begin{array}{l}\text { Failure load } \\
\qquad(\mathrm{kN})\end{array}$} & \multirow[b]{2}{*}{ Type of rupture } \\
\hline & & $80 \%$ load & $100 \%$ load & Rupture & & \\
\hline VC1 & 71,73 / Shear & 5,84 & 6,52 & 12,28 & 106,44 & $\begin{array}{l}\text { Substrate shearing / grout } \\
\text { rupture and detachment }\end{array}$ \\
\hline VC2 & 75,36 / Shear & 5,41 & 6,22 & 11,57 & 106,75 & $\begin{array}{l}\text { Substrate shearing / } \\
\text { grout detachment }\end{array}$ \\
\hline VC3 & 72,54 / Shear & 8,05 & 8,08 & 13,86 & 97,05 & $\begin{array}{l}\text { Substrate shearing / grout } \\
\text { rupture and detachment }\end{array}$ \\
\hline VC4 & 79,46 / Shear & 7,05 & 7,36 & 14,42 & 114,09 & $\begin{array}{l}\text { Substrate shearing / } \\
\text { grout rupture }\end{array}$ \\
\hline VC5 & 82,79 / Shear & 6,33 & 6,42 & 11,97 & 106,16 & $\begin{array}{l}\text { Substrate shearing / } \\
\text { grout detachment }\end{array}$ \\
\hline \multicolumn{6}{|c|}{ Average failure load $=106,10 \mathrm{kN}$} & \\
\hline
\end{tabular}

Table 9

Deformations in the components of the beams at the moment of failure

\begin{tabular}{|c|c|c|c|c|}
\hline Beams & $\begin{array}{c}\text { Upper surface } \\
\text { concrete/substrate } \\
(\% \circ)\end{array}$ & $\begin{array}{c}\text { Substrate longitudinal } \\
\text { tension reinforcement } \\
(\%)\end{array}$ & $\begin{array}{c}\text { Grout upper surface } \\
\text { (\%०) }\end{array}$ & $\begin{array}{c}\text { Longitudinal tension } \\
\text { reinforcement } \\
\text { (\%०) }\end{array}$ \\
\hline VC1 & 6,145 & 2,338 & 0,426 & 1,526 \\
\hline VC2 & 0,204 & 2,144 & 0,494 & $X$ \\
\hline VC3 & 0,368 & 2,198 & 0,386 & 1,036 \\
\hline VC4 & 2,003 & 2,448 & 0,635 & 1,683 \\
\hline VC5 & 0,449 & 1,678 & 0,452 & 1,349 \\
\hline
\end{tabular}

the average obtained for the displacement, in which it obtained a standard deviation of $1.24 \mathrm{~mm}(\mathrm{CoV}=9.67 \%)$.

- All the beams, after the strengthed, had pre-cracking due to shearing and suffered failure by shear of the substrate, varying due to the rupture and the detachment of the grout.

The deformation values for the strengthening beams with bonded steel connectors are listed in Table 9.

- The VC1 beam showed strain on the upper face of the incoherent substrate concrete in relation to the others. It should be noted that this value may have occurred due to failure of the constituent devices of the measurement system.

- The VC4 beam showed deformation in the upper face of the concrete substrate of $2.003 \%$, a considerably higher value when compared to the beams VC2, VC3 and VC5, but such deformation was possible considering the ULS deformations.

- The average strain in the longitudinal steel tension of the substrate at the instant of failure was $2.161 \%$, with a standard deviation of $0.295 \%$.

The average strain in the compressed face of the grout obtained at the instant of failure was $0,479 \%$, with a standard deviation of $0,096 \%$. The average deformation obtained at the failure instant was of $1,399 \%$ and standard deviation of $0.277 \%$ to longitudinal tensile of the reinforcement. It should be noted that for the calculation of the mean strain for the tensile strengthening steel bars, the deformation of the VC2 was not considered due to the fact that the data referring to this information were not recorded. The values presented and discussed for the failure load were different, indicating that the types of reinforcement influenced the results. For a more consistent analysis, the analysis of variance - ANOVA was performed, between the results of the group of reference beams, the beams with surface of the smooth interface and the beams with surface of the smooth interface with bonded steel connectors, considering the failure load. Although several beams have cracked due to shearing, the stiffness of the reinforced part may have influenced the stress distribution mechanisms, allowing the load variations to be verified. Table 10 shows the ANOVA values. It is verified that there is evidence that the type of reinforcement influenced the failure load, since $\mathrm{F}$ obtained was higher than Phytic and also, the P-value was less than 0,05.

\section{Conclusions}

The strengthening by casing using grout and reinforcing bars is a technique that allows to increase the maximum load capacity of the

\section{Table 10}

Analysis of variance - single fator

\begin{tabular}{|c|c|c|c|c|c|c|c|}
\hline Analysis in groups & SQ & gl & $M Q$ & $\mathbf{F}$ & P-value & $\mathbf{F}$ & Influence \\
\hline VR, VL e VC & 2723,92 & 2 & 1361,96 & 30,39 & 9,94E-05 & 4,256 & Yes \\
\hline \multicolumn{8}{|c|}{$\begin{array}{l}\mathrm{SQ} \text { is the sum of the squares of all deviations from the mean of all observations (between and within the samples); gl is the degree of freedom; MQ is the quadratic mean } \\
\text { (between and within the samples). }\end{array}$} \\
\hline \multicolumn{8}{|l|}{ Variance between samples } \\
\hline \multicolumn{8}{|l|}{$F=\overline{\text { Variance whitin the samples }}$} \\
\hline \multicolumn{8}{|c|}{$\begin{array}{l}\text { P-value is the probability that the null hypothesis is true. The significance level of the test was set at } 0.05 \text {. } \\
\text { F is the value calculated according to the level of significance and the degrees of freedom of the variances between and within the samples. }\end{array}$} \\
\hline
\end{tabular}


beams, being verified that there was an increase, in relation to the flexion, of $44.25 \%$ and $47.05 \%$ for smooth interface beams without and with steel connectors, respectively.

The calculation of the strength using the stress and strain states reached values close to those obtained during the test, when the safety coefficients were not taken into account.

It should be noted that the beams could have reached higher loading values if they had not failure by shearing of the substrate. For this reason it was considered that the maximum load capacity was not higher because all the beams after the reinforcement failed by shearing of the substrate.

The treatment of the surface, which consisted only in the removal of the layer of the cement dust, favored the adhesion when the grout was applied as a reinforcement material.

It was possible to verify that the average displacements of the reinforced beams (without and with connectors) were very close. The steel connector contributed, although in a small part (2.8\%), to the shearing strength acting at the interface, being the limiting factor the detachment of the concrete cover layer in which it was bonded. It should be noted that the initial objective of the research was to verify the possibility of using this type of connector, that is, without the appearance of cuttings in the beams. This objective was partially achieved and was promising.

\section{Acknowledgments}

The authors thank UFU - Federal University of Uberlandia for providing structure for this work.

\section{References}

[1] FÉDÉRATION INTERNATIONALE DU BÉTON - FIB. Model Code 2010. Switzerland, 2010. v. 1.

[2] REIS, A. P. A. Reforço de vigas de concreto armado por meio de barras de aço adicionais ou chapas de aço e argamassa de alto desempenho. Dissertação (Mestrado) - Escola de Engenharia de São Carlos, Universidade de São Paulo, 1998.

[3] SIMÕES, M. L. F. Reforço à flexão de vigas de concreto armado por encamisamento parcial. Dissertação (Mestrado) - Faculdade de Engenharia Civil, Universidade Federal do Rio de Janeiro, 2007.

[4] AMERICAN CONCRETE INSTITUTE - ACI 440.2R-08 Guide for the design and construction of externally bonded FRP systems for strengthening concrete structures. Farmington Hills. MI-USA. 2008.

[5] FÉDÉRATION INTERNATIONALE DU BÉTON - FIB. FRP reinforcement in RC structures. Technical Report. Bulletin 40. Switzerland, 2007

[6] ALTUN, F. An experimental study of the jacketed reinforcedconcrete beams under bending. In: Construction and Building Materials. v.18, 2004. p.611-618.

[7] ASSOCIAÇÃO BRASILEIRADE NORMAS TÉCNICAS. NBR 6118: Projeto de estruturas de concreto - Procedimento. Rio de Janeiro: 2014.

[8] AMERICAN CONCRETE INSTITUTE. ACI 318: Building Code Requirements for Structural Concrete and Commentary. Farmington Hills, MI-USA, 2011.
[9] CHEONG, H. K.; MACALEVEY, N. Experimental behavior of jacketed reinforced concrete beams. In: ASCE Journal of Structural Engineering. V.126, 2000. p.692-699.

[10] ASSOCIAÇÃO BRASILEIRADE NORMAS TÉCNICAS. NBR 8681: Ações e segurança nas estruturas - Procedimento. Rio de Janeiro: 2003.

[11] NBR 5739: Concreto - Ensaios de compressão de corpos-de-prova cilíndricos. Rio de Janeiro: 2007.

[12] _ NBR 8522: Concreto - Determinação do módulo estático de elasticidade à compressão. Rio de Janeiro: 2008.

[13] NBR 7480: Aço destinado a armaduras para estruturas de concreto armado - Especificação. Rio de Janeiro: 2007. 